\title{
THE INTERPRETATION OF ORDOVICIAN, SILURIAN AND DEVONIAN PALEOENVIRONMENTS UTILIZING THE DISTRIBUTION OF ACRITARCH ASSOCIATIONS AND ORGANIC PALYNOFACIES
}

DORNING, Ken J., Pallab Research, 58 Robertson Road, Sheffield S6 5DX, U.K.

Paleozoic acritarch and marine phytoplankton associations clearly interpret paleoenvironments within marine shelf and oceanic depositional areas. Marginal marine sediments are characterized by low diversity acritarch assemblages, while shelf areas contain a higher diversity of forms. Areas with significant terrestrial runoff tend to have higher phytoplankton abundance together with terrestrial palynomorphs in contrast to restricted circulation carbonate shelf areas with distinctive low abundance acritarch associations. Deep water basinal and oceanic areas with low phytoplankton nutrient availability are characterized by very low diversity acritarch associations of moderate to very low abundance. Within the Paleozoic, changes in relative sea level are indicated by the record of a series of acritarch associations reflecting changing depositional environments comparable to depositional sequences and parasequences. 